\title{
THE CORPORATE SUSTAINABILITY TYPOLOGY: ANALYSING SUSTAINABILITY DRIVERS AND FOSTERING SUSTAINABILITY AT ENTERPRISES
}

\author{
Winston JERÓNIMO SILVESTRE ${ }^{1}$, Paula ANTUNES ${ }^{1}$, Walter LEAL FILHO ${ }^{2}$ \\ ${ }^{1}$ CENSE - Center for Environmental and Sustainability Research, Department of Environmental \\ Sciences and Engineering, Faculdade de Ciências e Tecnologia, Universidade Nova de Lisboa, \\ Campus de Caparica, 2829-516 Caparica, Portugal \\ ${ }^{2}$ School of Science and the Environment, Manchester Metropolitan University, \\ Chester Street, Manchester, M1 5GD, United Kingdom
}

Received 25 May 2015; accepted 30 Jan 2016

\begin{abstract}
Much has been written about the need for more humane, ethical, socially just and transparent ways of doing business and performing entrepreneurial activities. Consistent with this, concepts such as sustainable development, corporate citizenship, corporate sustainability (CS), sustainable entrepreneurship, business ethics, and corporate social responsibility (CSR), among many others, have emerged. This diversity of expressions raises the need to development a new typology for to CS. This paper addresses this gap and describes a framework typology for corporate sustainability, by analysing sustainability drivers and the interactivity factors in the context of sustainability. It also describes the various types of sustainable emphasis given by companies and their associated levels of CS, which may pave the way for a new framework typology.
\end{abstract}

Keywords: business sustainability, triple bottom line, sustainability strategy, corporate sustainability typology, corporate social responsibility, corporate governance.

JEL Classification: Q01, Q56, L21, M14.

\section{Introduction}

Each organization has its unique course which evolves and changes and is the basis of its experience. Organizations carry out their activities in a given context in which they interact, get modified and transformed, as well as modify and transfer the impacts of their activities to their surroundings. Thus companies, through their actions as active subjects, make changes, affecting the economic, environmental and social dimensions of their context (Freeman, Hasnaoui 2011).

Corresponding author Winston Jerónimo Silvestre

E-mail:winstonjeronimo@gmail.com 
So, on the one hand we have the consumers and a whole group of different stakeholders who constantly seek to maximize their utility and, on the other hand, the company, which aims to obtain the best combination of labour and resources used in an efficient way.

Within the mentioned dynamic, companies generate a multitude of impacts. The intensity of these is directly related to the activity sector to which they belong (UN 2008), depending on the life cycle of their products and services (Finnveden et al. 2009), their supply chain (Govindan et al. 2014), the relationship established with the different stakeholders (Loorbach, Lijnis Huffenreuter 2013) and their social responsibility practices (Wood 2010).

Several approaches to these issues state that in recent years we are witnessing a shift of business paradigm and we need to be aware of the major economic, social and environmental challenges which ought to be addressed (Linnenluecke, Griffiths 2010). The main challenge is to decide which actions and initiatives should companies choose to meet the challenges of sustainability.

Companies which accept the challenge of sustainability generally get tangible and intangible benefits that translate into economic developments (Bird et al. 2007; Lee et al. 2013), are emotionally more appealing to work at (Linnenluecke, Griffiths 2010), are more attractive to investors (Searcy, Elkhawas 2012), exhibit better levels of reputation and governance (Mackenzie 2007) as well as high levels of product quality, innovation and social and environmental ethics (Allouche, Laroche 2005; Ghosh et al. 2014).

However, though there is an increase in the number of companies which choose sustainable behaviours, studies show that the general state of our planet is disquieting. This was confirmed by the Global Environmental Outlook GEO 5 (UNEP 2012). Thus, the improvements which are required at a global level the company's efforts are not enough to overcome them but also on concerted and comprehensive actions involving all stakeholders.

This discrepancy between the micro and the macro scale might be connected to our failure to assess accurately the impacts caused by companies. In this sense, Waddock and Grave (1997), state that there is no such thing as the best way or a single way to measure the activities of corporate sustainability. Labuschagne et al. $(2005,373)$ note that: "...the available tools do not adequately assist industry decision-makers (at company management level) who are required to assess and evaluate their operations in terms of internal and external impacts".

Similarly, Singh et al. (2007) concluded that there is still no comprehensive framework for the assessment of sustainability management at company level. Atlee and Kirchain (2006) recognize the difficulty in measuring corporate sustainable performance and progress in the context of operational decisions. This leads to corporate sustainability being based on the following axiom: "What gets measured, gets managed" because this way one can identify, plan and manage priorities and opportunities (Asif et al. 2013).

Thus, the debate on CSR is shifting from the possibility of making commitments to how to implement, maintain and improve CSR practices (Smith 2003). In this sense, there are three aspects which are interrelated and must be taken into account: the first aspect deals with the need for a systematic and planned approach (Porter, Kramer 2006; Baumgartner, Ebner 2010); the second aspect is the measurement and assessment of CSR to ensure that the business processes are regularly monitored and evaluated (Lee et al. 2012); and the third aspect is associated with communication to stakeholders (Fifka 2013). 
However, in corporate theory, both in conventional economics and in the approaches closer to the principles of sustainable economy, there continues to be a common denominator which is the obligation of the company to generate profit. On the definition given by Lozano et al. (2014: 1) this aspect is evidenced about sustainability oriented corporate theory: "The firm is a profit generating entity in a state of constant evolution".

This issue is emphasized by Kurucz et al. (2008), when he says that the potential relationship which rises from the need to be socially and environmentally responsible is justified by the increase in the company's financial performance, that is, according to the authors you need to "do well" (financially) in order to "do good" (act responsibly). However, it is not completely consensual both on the literature and empirical work that the social and environmental responsibility perspective of the company evolves positively or negatively depending on the results of their economic dimension. Thus, it is in ethics that lies all differentiation.

It is, therefore, crucial that companies take bold steps in the environmental and social dimensions, as genuine sustainability resides on the levels of well-being created today and for the future (WBCSD 2010). This task is not easy and involves a multitude of variables and constraints difficult to determine and control but it will have to be done (Ruckelshaus 1989).

This debate has been centred on implementing, maintaining and improving the CSR practices, and, additionally, on how to evaluate their impact and results (Mahoney et al. 2013). In other words, how to integrate the principles of sustainability in the company's strategic planning, the know-how capacity to reset its growth at all times, the ability to create market opportunities, the implementation of new ways of using and reusing resources, which approaches should be used to interact with and integrate the different stakeholders, what to measure and how to measure it to monitor and evaluate results and, finally, which communication channels should be used to publicize their intentions, proposals and results as creation of value and shared value (Porter, Kramer 2006, 2011; Asif et al. 2013; Fernandez-Feijoo et al. 2014).

However, and as Fiksel (2006) evidenced, companies are not all in the same context or have the same operational maturity. Thus, they will be more or less sustainable if they prove the ability to adapt proactively to different environments, which, by definition, are constantly changing.

The presence or absence of value created by the performance of the company's activities will be reflected on the sharing of resources for the dimensions of the triple bottom line (TBL) and this will influence positively or negatively its sustainability performance (Carroll, Shabana 2010; Sakalauskas 2010). Consequently, the result of the combination of different factors in TBL dimensions will lead to opportunities for operational improvements involving, according to Fiksel (2006), adaptive capacity to sustainability, allowing that this adaptive capacity will depend on the company and the business sector.

It is, therefore, important that the contribution of the sustainability practiced by the company might be typified. In this paper, the authors develop and describe a framework to assess the commitment and the positioning of the activity carried out by the company using a typology that characterizes it at different levels and dimensions and allows it to 
devise future sustainability strategies aiming at general well-being. The research methods used includes an analysis of corporate sustainability management and introduction to the general framework of sustainable company types.

\section{The problem of assessing to typify and position}

It would be expected that companies using the same recording and reporting systems in the same area of activity would be coincident, for example, with regard to the use and designation of specific indicators and frequency of their occurrence (Roca, Searcy 2012).

In the literature there is no consensus about metrics to quantify sustainability. On the one hand, some sustain that the existent metrics represent a conception of sustainability based in quantified data (Figge, Hahn 2004; O'Connor, Spangenberg 2008). On the other hand, some argue that the ambiguity of the sustainable development (SD) definition, the terminological confusion, the different ways of data collection, as well the lack of consistent measurement methodologies originate untrustworthy results (Kuosmanen, T., Kuosmanen, N. 2009).

Based on their research, Roca and Searcy (2012) assert, as probable causes for this lack of consensus, the inexistence of standardization as well as the manner the information is publicized, as the reports can be used for various purposes. In turn, Braungart et al. (2007) refer to the level of uncertainty presented by some of the measurement criteria, as well as by the fact that companies choose specific indicators to enhance objectives or legitimate interests.

To reduce the ambiguity, it would be important that decision makers understand what they are measuring, the type of methodologies and systems to be used, how the indicators react, their magnitude, and the way they relate to the sustainability which they intend to measure (Singh et al. 2009). Hence, on the one hand we have all the data and assessments and, on the other, we have the attitudes and decisions to be made which differ depending on the target group they are intended to: politicians, researchers, policy makers, investors and the general public.

However, it is recognized that sometimes it is not clear what can be considered and classified as a sustainable behaviour or attitude of the company. This depends of the expectations and perceptions that are being created, which vary and change according to the interactions that take place between the company and the stakeholders (Deegan 2006; Parmar et al. 2010). According to Kallio and Nordberg (2006) we still have little knowledge and fail to grasp the contribution and evaluation of corporate sustainability.

For Moneva et al. (2006) it is essential to identify the core values of what can be sustained and that is worth sustaining, as the gap between what is being done and what one really should be doing still exists and is growing. Companies play a key role and should contribute to the objectives of sustainable development (Fischer et al. 2007) by adopting an integrated view of opportunities, seeking not only efficiency but also efficacy on their actions and operational functionalities. This vision will enable the creation of value not only for the company but also for its surroundings (Porter, Kramer 2011) and thus create well-being. 
Therefore, we can infer that the sustainable company should be the one which practices systemic sustainability, strategically planned on the short, medium and long terms, by adopting creative management models. In order to do this, it will have to deal with all stakeholders in a transparent manner because their responsibility has precedence implications and their acts transcend the conclusion of a transaction, since this responsibility goes far beyond the service or product life cycle.

\section{Adaptive cycle of corporate sustainability}

A company is a multi-dimensional structure comprised of complex systems and subsystems that operate in a micro environment. Within this complexity, it should, at all times, adapt its behaviour in a balanced way. For Holling (2001: 399) adaptive cycles represent opportunities: "Sustainability is the capacity to create, test, and maintain adaptive capability. Development is the process of creating, testing, and maintaining opportunity. The phrase that combines the two, 'sustainable development' therefore refers to the goal of fostering adaptive capabilities while simultaneously creating opportunities". Thus, the companies' multidimensional structures are characterized by having processes of adaptive cycles which are defined as growth, accumulation, restructuring and renewal cycles. The present and future state of adaptive cycles is dependent of:

I. Potential: the capacity for change available in the system, which is related to the diversity of options available (Loorbach, Rotmans 2010);

II. Connectivity: the level of connection between the variables and processes which control the system self-regulation capacity and sensitivity to instabilities (Walker, Salt 2006);

III. Resilience: vulnerability of the systems to unexpected shock (Branzei, Abdelnour 2010).

Each phase is associated to a type of strategy that is dependent on the company's behaviour patterns. We have, therefore, defensive strategies which seek stability, exploration strategies pursuing new alternative solutions, analytical strategies which are a compromise between the defensive and the exploration options and, finally, reactive strategies which are considered a non-strategy since they are based on responding and acting on impulse (Moore, Manring 2009; Carroll, Shabana 2010).

It is accepted that the adoption of measures to achieve the sustainability of a given system requires prior analysis of the position the company occupies in the cycle process and in the type of strategy. Thus, certain actions can be triggered at different stages aiming at their greater efficiency. This means that management must also be adaptive and should identify uncertainties and establish methodologies for planning ahead of these same uncertainties by developing alternative responses to the system (transition management can be an option, Kemp et al. 2007). 


\section{The organizational boundaries}

The understanding of what are and how to define the organizational boundaries has been a central theme in the studies of organizational sustainability, spreading across various aspects and fields of interest. Thus, there is an understanding in the area of sustainability that the organizational border is not confined within itself. In this sense, the type of company will depend on the perception of its border and what it understands as society and environment.

The prevalent understanding of company boundaries is that this concept is not one-dimensional, i.e., companies have different boundary levels. For Santos and Eisenhardt (2005) the boundary of each company has distinct characteristics depending on the organization's assumptions and understanding of society and environment. The authors set forth and define four borders: the efficiency frontier, as a decision and atomized vision boundary; the idea of power, laying emphasis on the sphere of influence of the company; competence, which is connected to the ability to manage and construct from its combined resources; and, finally the identity "who we are". However, they maintain that the subset of the various boundaries contribute to the formulation and notion of a single limit.

In turn, Singh et al. (2009) argue that the company boundary is operational and is directly related to performance evaluation. This limit is associated to all the impacts generated by its business cycle.

Other authors understand the organizational boundary as the effective control of the company by its "government", which is legitimized by its shareholder structure by empowering them to define the strategic planning and manage the business operating procedures (Moneva et al. 2006; Hasnas 2012).

For P. B. Henning and G. K. Henning (2013), corporate boundaries are intrinsic to their various systems and their sustainability will be dependent on the quality of the relationships established at their borders that is how the organization affects society and the environment with their products and services and how they react to their impacts. They assert that the organizational boundary is a "sphere of concerns" wherein some companies regard society and the environment as instruments for their success and profit while others are an instrument for society and the environment.

As Jantsch (1980) states, paradoxically, sustainability often requires systematic destabilization on the company borders. The needs of society and the environment change and this forces companies to be systematically in a process of "creative change" of its borders. Thus, the organizational sustainable border should strategically be more attentive to the evolution of future changes, evolving with the social and environmental needs of the context in which is inserted (prevention approach) instead of keeping present practices closer to business-as-usual. 


\section{Sustainability drivers}

\subsection{Endogenous drivers}

Three features will be taken into consideration as internal forces:

- Strategy: the level of integration of sustainability principles in strategic business processes is a prerequisite for sustainability operationality (Graafland, van de Ven 2006; Porter, Kramer 2006; Baumgartner, Ebner 2010). However, Etzion (2007) argues on this subject that companies tend to look at sustainability strategies as a distinct aspect of their core strategy. In some cases, refered to by Ramanathan et al. (2010), companies integrate sustainability considerations only to adjust their procedures and adjust to demands and regulations, while other companies are proactive in integrating sustainability strategies in their main strategies. Nonetheless, for Ekins (2005) obtaining efficient results between TBL dimensions in the case of, for example, eco-efficiency can contribute to the integration of sustainability principles in key strategic processes.

- Organizational culture: several studies have demonstrated that communication and accurate and timely information have positive effects on the implementation of sustainability in organizational culture (Lenox, King 2004) strengthening the organization motivation, legitimacy and responsibility (Wood 2010).

- Resources: company must ensure their competitive advantage. Barney (2000) considers that this advantage arises when the company respects and explores its resources in an appropriate way. Thus, the sustainable success of the company will depend on the convenient use that makes of its different capitals, either tangible or intangible. As Dyllick and Hockerts (2002) note, the capitals associated with TBL have different properties and characteristics, and should, therefore, be approached and dealt with in different manners.

\subsection{Exogenous drivers}

Three features will be taken into consideration as external forces:

- Rules and regulations: this group comprises all legal regulations and others that the company will have to necessarily follow or endure sanctions which affect its reputation and image (Wood 2010; Asif et al. 2013). The imposition of rules and regulations has proven to be a key process to lead towards sustainability (Etzion 2007).

- Social values and norms: this group refers to the stakeholders that somehow interact and pressure the companies. These are dynamic groups that can lead public opinion, beliefs and values in what concerns given events (Rivera-Camino 2007). The Companies should consider them, as well as integrate them in their sustainability processes.

- Market: it represents all stakeholders who interact with the company (customers, suppliers, shareholders, competitors) and react positively or negatively to its initiatives. For example, suppliers may suspend product supply agreements or partnerships if their reputation is jeopardized by the activities of his clients; shareholders may re- 
fuse to support the company financially if it has a rich environmental management; customers can opt for company "A" instead of company "B" because of its recognized CSR practices (Rivera-Camino 2007; Porter, Kramer 2011).

\section{The company: a dynamic driver of change}

In any evolutionary process the most noticeable constant is the one which has to do with change. It is within the dynamics of this "constant" that all development models are measured using as reference of its impact, the magnitude of the existing gradient between the positive and negative aspects of its development as part of any process of change.

One of the characteristics of human systems has been their particular interest in increasing the "constant" of change at an accelerated rate (Barney 2000), by adopting shorter and shorter transformation cycles which are accompanied by a multiplicity of factors which produce precedence impacts, and, therefore, affect several systems. On the other hand, the increase of these changes has fostered a progressively higher degree of complexity in all systems where human activities are conducted.

There are countless examples of this "constant" of change: economic growth and downturns, development and accelerated implementation of technologies, changes in social interrelations structures and alteration of natural balances, among many others.

Companies, as dynamic drivers of change, have been one of the systems which probably have contributed the most to change because of their complexity, whether due to the production factors they involve, to the consumption of products and services placed on the market (Stuart et al. 2003) or due to the social changes that they have promoted (Mu et al. 2011).

Many of the problems caused by the dynamics brought about by companies have led to the perpetuation of direct effects, which have been the consented cause of degradation of other systems. There is also a positive side to their actions but in some spheres it is not enough to balance the negative aspects of their influence.

Still, with some frequency the options chosen in an attempt to solve the problems caused by their pattern of growth reveal flaws, aggravating them or creating new problems (Walker, Salt 2006).

The complexity and amount of information have turned us into systemic thinkers of problems that are far beyond our mental models. The idea of having or seeking the solution for the whole often leads us away from paying the necessary attention to the parts of the problem. They can provide clues and explanations to understand and solve more complex situations in change processes.

\section{Capital: interactivity factors in the context of sustainability}

Sustainability is a global concept, hence each company represents a micro fraction of the whole system, with different coverage levels. Van Passel et al. (2007) states that the company's interactions with the various systems that surround it are of great variety and intensity and its impact and importance as a transformative agent has global implications. They are 
key actors in contributing to sustainability and their technical capacity and strength are fundamental to achieve it. Figure 1 presents the interactive factors based on capital theory.

Corporate sustainability management is based on the balanced management of the capitals which are available to them as well as a broader interpretation of what capital is. They should, therefore, be approached and dealt with distinctively.

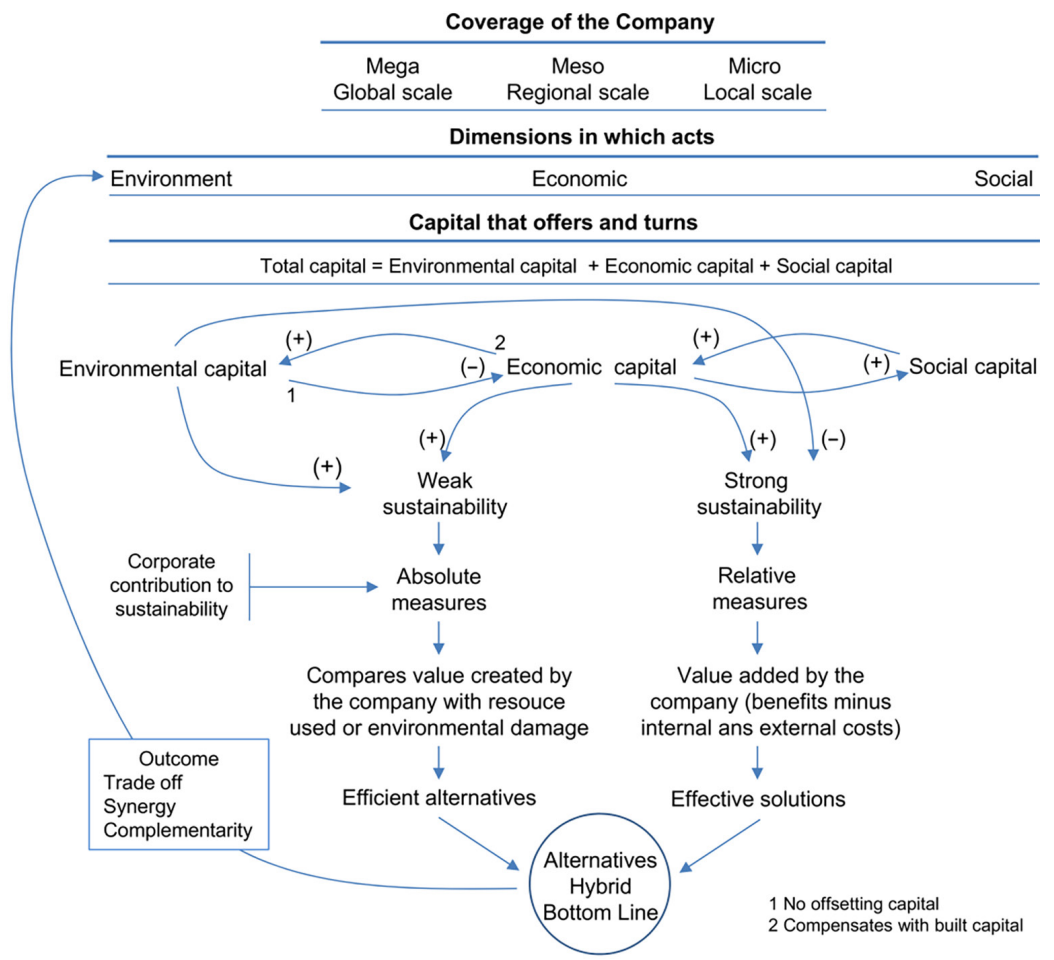

Fig. 1. Cycle of interactive capital

One of the ways companies have to give an account of the flows and impacts occurred in their capitals is by publishing reports. The information and data reported by the company are assumed to be consistent and represent faithfully the way they carry out their activities, as well as the commitments made in the implementation of solutions aimed at sustainability. However, the activities of the company are dependent of its perception of its boundaries and what should or should not be reported between the organization and its context. This means that a substantial part of the impacts might not be described accurately, especially indirect impacts, by focusing their attention mainly on the direct impacts which are controlled by the company (Archel et al. 2008).

It is consensual (Rodrigo 2012; Fernandez-Feijoo et al. 2014; Gomes 2015) that there are three ways the commitments to sustainability may be implemented by a company:

I. Involuntary: not strategically structured, non-comprehensive and implemented through the coercive imposition of legal norms (a regulatory structure can regulate 
the most harmful forms of unsustainable behaviour by creating minimum standards or prohibiting specific activities);

II. Voluntary: not dependent of legal impositions, adopts differentiating options and policies in their planning in order to minimize impacts (both direct and indirect); implements complementary strategies to address medium and long term solutions;

III. Market criteria: creates the basic conditions for the market criteria to be same for all companies.

However, the constant search for zero waste, zero resources, zero impact ultimately makes the connection between financial and ecological objectives permanently unstable, as stated by Braungart et al. (2007). In fact, the strategies for TBL don't result in equilibrium for the economic, social and environmental dimensions because the economic goals consistently remain a priority, while the goals to be achieved for the other dimensions are devised for an acceptable minimum performance.

The relationship between generating and adding value involves the ability the company demonstrates to develop strategies that ensure the viability of its business overtime. This introduces a critical matter to the company, associated with the ability to balance shortterm operating costs and potential future benefits, as well as the need for maintaining a capital structure that guarantees its operational capacity.

It should be noted that certain costs and values associated to the TBL are based on concepts that are difficult to quantify (intangibility of results). These concepts themselves seem like feasible ideas. However, when one tries to place a value on them, so that it is possible to assess and measure their contribution to sustainability as a whole, it proves to be extremely difficult to concretize. This is the case, for example, of social justice, ecosystem services and environmental degradation. Similarly, this difficulty extends to capital stock. By approaching capital theory within DS, three types of assets with different characteristics can be found, as previously mentioned: natural capital, economic capital, social capital (human). But we still have to consider built capital. Thus, the total capital is comprised of natural capital (resources) and economic, social and built capital.

The relationship and combination between these capitals leads to two different notions of sustainability: weak sustainability and strong sustainability (Neumayer 2010) and the fundamental difference between them lies in the possibilities of substitution between natural capital and the other capitals. Within the company, the development of its activities will inevitably be divided between these two dimensions of sustainability and its impact will depend on the concerted strategy of giving preference to one over the other or aiming at a possible balance between the two (Jerónimo Silvestre et al. 2014).

\section{Types of sustainable companies and their associated levels of sustainability}

Companies have been gradually adopting in their business processes several practices which aim to integrate the TBL dimensions (Fernandez-Feijoo et al. 2014). However, it is necessary to distinguish between companies and their practices and determine the actual contribution of these practices in terms of sustainability. Thus, corporate sustainability re- 
sides in the way companies integrate social, environmental and economic aspects in their business strategies in the short, medium or long term. The analysis of the literature and the different approaches studied allowed us to select a set of dimensions which address different aspects that, in our understanding, make it possible to typify the company's efforts towards sustainability.

The proposition that we will develop is not based on the market (the value attributed by company shareholder and stakeholders) but on the company itself. The goal is to determine the set of features which enable the creation of a typology sustainable company.

The result of the company's positioning will allows us to verify the efficiency and the effectiveness of the measures and actions developed within the functional processes of the company that best balance the economic, social and environmental dimensions (Figge, Hahn 2004, 2013; Lamberton 2005).

Traditional approaches in this area generally contrast the environmental and social value created by a company with the damage it causes (Moneva et al. 2006; Boiral 2013) with no reference to the level of their contribution to sustainability.

Table 1 shows a structure which describes the types of sustainable companies and their levels of sustainability. This structure allows us to position the company taking into consideration its initiatives, activities and operational strategies.

Table 1. General framework of the key features in each type of sustainable company and their associated levels of sustainability

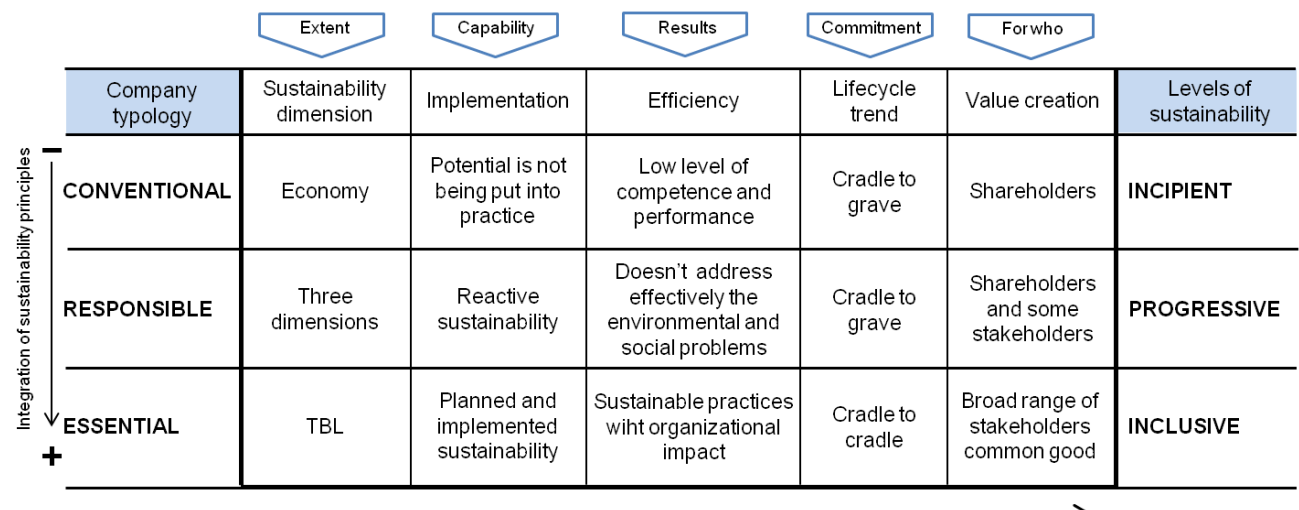

Thus, our proposal is based on the following: at each moment the company is responsible for the promotion of the changes that it implements (EC 2011). These changes must be supported by the experience of accumulated knowledge and must promote an effective transformation to increasingly higher conciliating levels in the relationship of the company with the stakeholders and surroundings. This means that the company must trigger processes for knowledge transfer (objects and knowledge) that induce gradual, continuous, progressive and contagious sustainability, within the required limits to achieve some level of bio-anthropological well-being (Jerónimo Silvestre et al. 2014). 
The aim is to determine the level of the company is in each moment, and where it should focus its attention to get the highest contribution towards effective corporate sustainability (Lamberton 2005). The goal will be to, simultaneously, verify the efficiency and effectiveness of developed measures (Alexander 2013) and actions by the company in the economic, social and environmental dimensions.

\subsection{Dimensions of the general framework of sustainable company type}

The framework above defines a set of dimensions which outline and give meaning to the business typologies. They are described below:

Extent: which TBL dimensions and their associated capitals are being taken into account by the company (Hubbard 2009; Halpern et al. 2013). The strategies of the activities to be undertaken by the company are defined in this dimension, as well as the goals to be achieved (Porter, Kramer 2006; Baumgartner, Ebner 2010). A perspective of short, medium and long term actions should be included in this dimension.

Capacity: in this dimension the main objective is to enhance and disseminate the principles of sustainability defined by the organization (Wood 2010). To develop practices that take into account risk and opportunity management (Aven 2011) and execute planned actions.

Result: translate the actions planned into results, evaluating and monitoring their progress (Gibson et al. 2005; Sheate 2012).

Commitment: the perception of what it means to integrate the social and environmental aspects with each other and each of them with the economic dimension in order to achieve business sustainability is not linear. However, it is up to the company to reduce the impacts on its value chain, trying to balance the effects on the lifecycle of its products and services (Braungart et al. 2007).

For whom: in the perspective of economic, social and environmental value. In this way we have the creation of direct value managed or shared value (Porter, Kramer 2011) depending on the type of stakeholders.

\subsection{Typology of sustainable businesses}

To typify what is a sustainable company we refer to the dimensions described on the previous paragraph. As shown in Table 1, each of the dimensions described was characterized: Sustainability dimension (Extent): depending on the company perspective, it can operate in a one-dimensional system, in which its main concern focuses on the economic aspects ("business-as-usual"), or it operates in a multidimensional perspective based on sustainability considering the three dimensions (economic, environmental, social) or in an integrated process which pays equal importance to all the TBL dimensions.

Implementation (Capacity): depending on the endogenous and exogenous forces, the company should define and integrate into its guidelines strategies and options which contribute to consolidate the organizational culture that supports the shift to sustainability. This transformation will be achieved through the company behaviour and the levels of 
responsibility of their products and services. The implementation of sustainability may start from a conventionally business and evolve to new forms. These forms may include unconventional aspects and sometimes even be radical, giving answers to problems from a new perspective, taking imaginative approaches which enable the company to reach other levels of understanding of sustainability, that is, new intervention boundaries.

Efficiency (Result): it is understood as the capacity that the company has to dispose of the different capitals and use them to achieve a given result. The difference between the objective and the effect achieved will give us an assessment of the sustainability practiced and accomplished.

Lifecycle trend (Commitment): alternative production and consumption strategies which aim to develop processes that tend to pursue zero emissions and principles of eco-efficiency in order to reduce the negative impacts by incorporating social, economic and environmental benefits in their procedures (Braungart et al. 2007).

Value creation (For whom): it remains the company's goal to create economic value that can be measured in several ways as, for instance, profit, return on assets and market value. Thus, the first to benefit by this added value are the capital owners (shareholders). From a sustainability perspective, value creation is obtained by achieving a balance of the capitals that make up TBL, which serve a broader set of stakeholders and will ultimately serve the common good both in the present and future time.

Both the dimensions as their typological characterization allows us to define the types of companies according to their level of commitment to sustainability. Table 2 shows the definition and differentiation by company type.

The analysis of a series of studies (McWilliams et al. 2006; Porter, Kramer 2006; Hubbard 2009; Carroll, Shabana 2010; Vitaliano 2010; Sheate 2012; Halpern et al. 2013; Urban, Nikolov 2013) allows us to consider a different set of key aspects which enclose characteristics that, in our view, help to understand better the business typologies and their actions.

Table 2. Differentiation between types of sustainable enterprises

\begin{tabular}{|c|c|c|}
\hline Conventional & Responsible & Essential \\
\hline $\begin{array}{l}\text { Company which assumes the } \\
\text { paradigm of economic profit } \\
\text { as its central reference. Its } \\
\text { reference stakeholder is the } \\
\text { shareholder. It does not make } \\
\text { an appropriate management of } \\
\text { risks and opportunities. Meets } \\
\text { the minimum requirements } \\
\text { as far as its responsibilities } \\
\text { are concerned. Sustainability } \\
\text { is not an integral part of their } \\
\text { immediate strategic concerns. }\end{array}$ & $\begin{array}{l}\text { Embraces CSR principles. In } \\
\text { addition to the shareholders it } \\
\text { regards other stakeholders as } \\
\text { references for their activities. } \\
\text { Promotes risk management } \\
\text { and opportunities. Includes in } \\
\text { its strategies the principles of } \\
\text { sustainability. Is concerned with } \\
\text { managing the dimensions of } \\
\text { sustainability. }\end{array}$ & $\begin{array}{l}\text { Company integrating } \\
\text { sustainability as its main } \\
\text { strategic orientation. Strives } \\
\text { to minimize its impact by } \\
\text { implementing solutions and } \\
\text { alternatives both up and } \\
\text { down stream of its activities. } \\
\text { Considers the dimensions of } \\
\text { TBL and its associated capitals } \\
\text { as part of a whole. It has an } \\
\text { inclusive relationship with all } \\
\text { of his stakeholders. Sharing its } \\
\text { created value has the ultimate } \\
\text { goal of creating common well- } \\
\text { being. }\end{array}$ \\
\hline
\end{tabular}


Table 3 shows the various key aspects mentioned. Needless to say that nothing is obvious and these aspects should be interpreted and judged through the performance and perception that the companies have of them and also by their understanding of CSR.

Table 3. Key features for the characterization on company types

\begin{tabular}{|c|c|c|c|}
\hline \multirow{2}{*}{ Key features } & \multicolumn{3}{|c|}{ Company Typology } \\
\hline & Conventional & Responsible & Essential \\
\hline $\begin{array}{l}\text { Willingness } \\
\text { to act }\end{array}$ & Reluctance to change & $\begin{array}{l}\text { Systematic application of } \\
\text { legal norms }\end{array}$ & Pro-activity \\
\hline Behaviour levels & $\begin{array}{l}\text { Lack of awareness or } \\
\text { knowledge }\end{array}$ & $\begin{array}{l}\text { Assume the need to } \\
\text { change }\end{array}$ & $\begin{array}{l}\text { Influencers are seen as } \\
\text { models to encourage the } \\
\text { adoption of different and } \\
\text { particular behaviours }\end{array}$ \\
\hline $\begin{array}{l}\text { Regulations, } \\
\text { customs and } \\
\text { habits }\end{array}$ & $\begin{array}{l}\text { Maintenance of their } \\
\text { habits and customs }\end{array}$ & $\begin{array}{l}\text { Implement changes on } \\
\text { their habits and customs } \\
\text { using normative ways }\end{array}$ & $\begin{array}{l}\text { Their behaviour is often } \\
\text { driven to change other } \\
\text { entities }\end{array}$ \\
\hline Changing costs & $\begin{array}{l}\text { Understood as a major } \\
\text { obstacle }\end{array}$ & $\begin{array}{l}\text { Financial measures may } \\
\text { be particularly effective in } \\
\text { driving change }\end{array}$ & Seen as an investment \\
\hline Conviction & $\begin{array}{l}\text { Lack of confidence in } \\
\text { their abilities }\end{array}$ & Take on challenges & $\begin{array}{l}\text { Believe that their } \\
\text { behaviour can make a } \\
\text { difference }\end{array}$ \\
\hline Terminology & Ignorance & Identify & Create terminology \\
\hline $\begin{array}{l}\text { Relative } \\
\text { sustainability }\end{array}$ & $\begin{array}{l}\text { Trial on a single } \\
\text { behaviour }\end{array}$ & Inter-related activities & $\begin{array}{l}\text { Operate on } \\
\text { multidimensional } \\
\text { interrelationships }\end{array}$ \\
\hline Governance & $\begin{array}{l}\text { Maximize the benefit of } \\
\text { their investors }\end{array}$ & $\begin{array}{l}\text { Maximize the benefit of } \\
\text { their investors. A portion } \\
\text { of the earnings reverse } \\
\text { to offset some of the } \\
\text { negative externalities } \\
\text { produced at the social } \\
\text { level }\end{array}$ & $\begin{array}{l}\text { Maximize society wealth } \\
\text { creation by providing } \\
\text { health products and } \\
\text { services }\end{array}$ \\
\hline Markets & $\begin{array}{l}\text { Comply with the rules in } \\
\text { market practice }\end{array}$ & $\begin{array}{l}\text { Seek to avoid the bad } \\
\text { effects that their products } \\
\text { and services may have }\end{array}$ & $\begin{array}{l}\text { Profits from the } \\
\text { competitive advantage } \\
\text { opportunities that they } \\
\text { create and plan }\end{array}$ \\
\hline Stakeholders & $\begin{array}{l}\text { Answer information } \\
\text { requests }\end{array}$ & Show social commitment & $\begin{array}{l}\text { Promote the integration } \\
\text { of stakeholders in the } \\
\text { company to find conjoint } \\
\text { solutions }\end{array}$ \\
\hline Placement & $\begin{array}{l}\text { The new requirements } \\
\text { of the liabilities shall } \\
\text { produce legal norms to be } \\
\text { followed by all }\end{array}$ & $\begin{array}{l}\text { The new responsibilities } \\
\text { assumed favour the } \\
\text { company performance }\end{array}$ & $\begin{array}{l}\text { Assuming responsibilities } \\
\text { allow the differentiation } \\
\text { of the company from all } \\
\text { the others }\end{array}$ \\
\hline Positioning & Reactivity & Pro-activity & Leadership \\
\hline Communication & As a mean for promotion & As a mean for promotion & $\begin{array}{l}\text { As a mean for } \\
\text { information }\end{array}$ \\
\hline
\end{tabular}




\section{Corporate sustainability levels}

The assessment of sustainability can be determined by the ratio between the aggregate benefits and costs of a given system (Figge, Hahn 2004; López et al. 2007). The holistic relationship that exists between economic prosperity levels, environmental quality and social justice is influenced both by the choices made and company practices (Asif et al. 2013). The result obtained, intra and inter-relationship in TBL dimensions, for every moment of a temporal continuum is what we may designate as sustainability levels.

Along these lines, a characterization of the level of sustainability was created for each typology. The characterization was performed according to the described typology and represents the ability the company shows in mitigating its impacts and how it manages its perception of CSR and the capitals associated with the economic, social and environmental dimensions. Table 4 describes the levels proposed.

Table 4. Characterization of sustainability levels by type of company

\begin{tabular}{|c|c|c|}
\hline $\begin{array}{c}\text { Levels of } \\
\text { sustainability }\end{array}$ & Characterization & $\begin{array}{l}\text { Company } \\
\text { typology }\end{array}$ \\
\hline Incipient & $\begin{array}{l}\text { 1. Companies in a state of alienation in what concerns the effects } \\
\text { of their impacts; } \\
\text { 2. Focused on obtaining short-term benefits, without considering } \\
\text { the consequences and risks of their choices; } \\
\text { 3. Permanent conflict with the supply and demand ratio, } \\
\text { presenting production levels which are not in line with real } \\
\text { consumption needs; } \\
\text { 4. Inefficient in what they produce and consume; } \\
\text { 5. Development is dictated by dominant market trends. }\end{array}$ & Conventional \\
\hline Progressive & $\begin{array}{l}\text { 1. Companies which try to connect with their stakeholders; } \\
\text { 2. Actions directed to solving specific problems; } \\
\text { 3. Focus their strategies on specific areas and do not apply a cross- } \\
\text { sectional approach; } \\
\text { 4. Governance uses the resources available to, alternately, promote } \\
\text { the interests of the company and benefit the shareholders; } \\
\text { 5. Takes environmental and social issues into consideration but } \\
\text { does not know how to handle these dimensions. }\end{array}$ & Responsible \\
\hline Inclusive & $\begin{array}{l}\text { 1. Companies which think, plan and act in interdisciplinary and } \\
\text { interdependent way; } \\
\text { 2. Work toward an alternative rationale, based on different models } \\
\text { of development and creative management; } \\
\text { 3. Consider the different areas of the company's operations, } \\
\text { analysing the interrelationships and the processes of change } \\
\text { over time; } \\
\text { 4. Promote individual change as an instrument of global } \\
\text { transformation; } \\
\text { 5. Strive to allocate resources in order to achieve the highest } \\
\text { efficiency in the TBL relation. }\end{array}$ & Essential \\
\hline
\end{tabular}




\section{Conclusions}

As this paper has attempted to demonstrate, the framework typology suggested can be very helpful in fostering a better understanding of the emphasis given to sustainability, and of what they may do mitigate their socio-environmental impacts. It can also help it to manage its perception of CSR on the one hand, and the capitals associated with the economic, social and environmental dimensions, on the other. It is widely acknowledged that companies are responsible to society as a whole, of which they are an integral part. By having a better understanding of the typology most appropriate to them, they may be in a better position to respond to changing circumstances and new challenges, also allowing them to fundamentally rethink their position and subsequently act in a manner consistent with the socio-economic and environmental context of which they are part of.

\section{References}

Alexander, S. 2013. Voluntary simplicity and the social reconstruction of law: degrowth from the grassroots up, Environmental Values 22(2): 287-308. http://dx.doi.org/10.3197/096327113X13581561725356

Allouche, J.; Laroche, P. 2005. A meta-analytical investigation of the relationship between corporate social and financial performance, Revue de Gestion des Ressources Humaines 57(1): 8-41.

Archel, P.; Fernández, M.; Larrinaga, C. 2008. The organizational and operational boundaries of triple bottom line reporting: a survey, Environmental Management 41(1): 106-117. http://dx.doi.org/10.1007/s00267-007-9029-7

Asif, M.; Searcy, C.; Zutshi, A.; Fisscher, O. A. M. 2013. An integrated management systems approach to corporate social responsibility, Journal of Cleaner Production 56: 7-17. http://dx.doi.org/10.1016/j.jclepro.2011.10.034

Atlee, J.; Kirchain, R. 2006. Operational sustainability metrics assessing metric effectiveness in the context of electronics-recycling systems, Environmental Science and Technology 40(14): 4506-4513. http://dx.doi.org/10.1021/es0509351

Aven, T. 2011. On the new ISO guide on risk management terminology, Reliability Engineering and System Safety 96(7): 719-726. http://dx.doi.org/10.1016/j.ress.2010.12.020

Barney, J. B. 2000. Firm resources and sustained competitive advantage, in J. A. C. Baum, F. Dobbin (Eds.). Economics Meets Sociology in Strategic Management. Volume 17. Emerald Group Publishing Limited, 203-227. http://dx.doi.org/10.1016/S0742-3322(00)17018-4

Baumgartner, R. J.; Ebner, D. 2010. Corporate sustainability strategies: sustainability profiles and maturity levels, Sustainable Development 18(2): 76-89. http://dx.doi.org/10.1002/sd.447

Bird, R. D.; Hall, A.; Momentè, F.; Reggiani, F. 2007. What corporate social responsibility activities are valued by the market?, Journal of Business Ethics 76(2): 189-206. http://dx.doi.org/10.1007/s10551-006-9268-1

Boiral, O. 2013. Sustainability reports as simulacra? A counter-account of A and A+ GRI reports, Accounting, Auditing and Accountability Journal 26(7): 1036-1071. http://dx.doi.org/10.1108/AAAJ-04-2012-00998

Branzei, O.; Abdelnour, S. 2010. Another day, another dollar: enterprise resilience under terrorism in developing countries, Journal of International Business Studies 41(5): 804-825. http://dx.doi.org/10.1057/jibs.2010.6

Braungart, M.; McDonough, W.; Bollinger, A. 2007. Cradle-to-cradle design: creating healthy emissions - a strategy for eco-effective product and system design, Journal of Cleaner Production 15(1314): 1337-1348. http://dx.doi.org/10.1016/j.jclepro.2006.08.003 
Carroll, A. B.; Shabana, K. M. 2010. The Business case for corporate social responsibility: a review of concepts, research and practice, International Journal of Management Reviews 12(1): 85-105. http://dx.doi.org/10.1111/j.1468-2370.2009.00275.x

Deegan, C. 2006. Financial accounting theory. $2^{\text {nd }}$ ed. Australia, Sydney: McGraw-Hill Book Company, 576.

Dyllick, T.; Hockerts, K. 2002. Beyond the business case for corporate sustainability, Business Strategy and the Environment 11(2): 130-141. http://dx.doi.org/10.1002/bse.323

EC. 2011. Communication from the Commission to the European Parliament, the Council, the European economic and social committee and the committee of the regions, a renewed EU strategy 2011-2014 for Corporate Social Responsibility [online], [cited 12 March 2014]. European Commission, 3-15. Available from Internet: http://eur-lex.europa.eu/LexUriServ/LexUriServ.do?uri=COM:2011:0681: FIN:PT:PDF

Ekins, P. 2005. Eco-efficiency: motives, drivers, and economic implications, Journal of Industrial Ecology 9(4): 12-14. http://dx.doi.org/10.1162/108819805775247981

Etzion, D. 2007. Research on organizations and the natural environment, 1992-Present: a review, Journal of Management 33(4): 637-664. http://dx.doi.org/10.1177/0149206307302553

Fernandez-Feijoo, B.; Romero, S.; Ruiz, S. 2014. Commitment to Corporate social responsibility measured through global reporting initiative reporting: factors affecting the behavior of companies, Journal of Cleaner Production 81(0): 244-254. http://dx.doi.org/10.1016/j.jclepro.2014.06.034

Fifka, M. S. 2013. Corporate responsibility reporting and its determinants in comparative perspective a review of the empirical literature and a meta-analysis, Business Strategy and the Environment 22(1): 1-35. http://dx.doi.org/10.1002/bse.729

Figge, F.; Hahn, T. 2004. Sustainable Value Added-measuring corporate contributions to sustainability beyond eco-efficiency, Ecological Economics 48(2): 173-187.

http://dx.doi.org/10.1016/j.ecolecon.2003.08.005

Figge, F.; Hahn, T. 2013. Value drivers of corporate eco-efficiency: management accounting information for the efficient use of environmental resources, Management Accounting Research 24(4): 387-400. http://dx.doi.org/10.1016/j.mar.2013.06.009

Fiksel, J. 2006. Sustainability and resilience: toward a systems approach, Sustainability Science, Practice, and Policy 2(2): 14-21.

Finnveden, G.; Hauschild, M. Z.; Ekvall, T.; Guinée, J.; Heijungs, R.; Hellweg, S.; Annette, K.; David, P.; Sangwon, Suh. 2009. Recent developments in Life Cycle Assessment, Journal of Environmental Management 91(1): 1-21. http://dx.doi.org/10.1016/j.jenvman.2009.06.018

Fischer, J.; Manning, A. D.; Steffen, W.; Rose, D. B.; Daniell, K.; Felton, A.; et al. 2007. Mind the sustainability gap, Trends in Ecology and Evolution 22(12): 621-624.

http://dx.doi.org/10.1016/j.tree.2007.08.016

Freeman, I.; Hasnaoui, A. 2011. The meaning of corporate social responsibility: the vision of four nations, Journal of Business Ethics 100(3): 419-443. http://dx.doi.org/10.1007/s10551-010-0688-6

Ghosh, S.; Buckler, L.; Skibniewski, M. J.; Negahban, S.; Kwak, Y. H. 2014. Organizational governance to integrate sustainability projects: a case study, Technological and Economic Development of Economy 20(1): 1-24. http://dx.doi.org/10.3846/20294913.2014.850755

Gibson, R. B.; Holtz, S.; Tansey, J.; Whitelaw, G.; Hassan, S. 2005. Sustainability assessment: criteria and processes. London: Earthscan, 180-188.

Gomes, C. M.; Kneipp, J. M.; Kruglianskas, I.; Rosa, L. A. B.; Bichueti, R. S. 2015. Management for sustainability: an analysis of the key practices according to the business size, Ecological Indicators 52: 116-127. http://dx.doi.org/10.1016/j.ecolind.2014.11.012

Govindan, K.; Azevedo, S. G.; Carvalho, H.; Cruz-Machado, V. 2014. Impact of supply chain management practices on sustainability, Journal of Cleaner Production 85: 212-225.

http://dx.doi.org/10.1016/j.jclepro.2014.05.068 
Graafland, J.; van de Ven, B. 2006. Strategic and moral motivation for corporate social responsibility, Journal of Corporate Citizenship 2006(22): 111-123. http://dx.doi.org/10.9774/GLEAF.4700.2006.su.00012

Halpern, B. S.; Klein, C. J.; Brown, C. J.; Beger, M.; Grantham, H. S.; Mangubhai, S.; et al. 2013. Achieving the triple bottom line in the face of inherent trade-offs among social equity, economic return, and conservation, Proceedings of the National Academy of Sciences: 1-5. http://dx.doi.org/10.1073/pnas.1217689110

Hasnas, J. 2012. Reflections on corporate moral responsibility and the problem solving technique of Alexander the Great, Journal of Business Ethics 107(2): 183-195. http://dx.doi.org/10.1007/s10551-011-1032-5

Henning, P. B.; Henning, G. K. 2013. Organizational sustainability and systemic boundary processes, Journal of Organisational Transformation and Social Change 10(2): 104-123. http://dx.doi.org/10.1179/1477963313Z.00000000012

Holling, C. S. 2001. Understanding the complexity of economic, ecological, and social systems, Ecosystems 4(5): 390-405. http://dx.doi.org/10.1007/s10021-001-0101-5

Hubbard, G. 2009. Measuring organizational performance: beyond the triple bottom line, Business Strategy and the Environment 18(3): 177-191. http://dx.doi.org/10.1002/bse.564

Jantsch, E. 1980. The self-organizing universe: scientific and human implications of the emerging paradigm of evolution. Toronto, ON: Pergamon Press.

Jerónimo Silvestre, W.; Antunes, P.; Leal Filho, W. 2014. Hybrid Bottom Line: another perspective on the sustainability of organizations, International Journal of Sustainable Development and World Ecology 21(5): 456-464. http://dx.doi.org/10.1080/13504509.2014.959580

Kallio, T. J.; Nordberg, P. 2006. The evolution of organizations and natural environment discourse: some critical remarks, Organization and Environment 19(4): 439-457. http://dx.doi.org/10.1177/1086026606294955

Kemp, R.; Loorbach, D.; Rotmans, J. 2007. Transition management as a model for managing processes of co-evolution towards sustainable development, International Journal of Sustainable Development and World Ecology 14(1): 78-91. http://dx.doi.org/10.1080/13504500709469709

Kuosmanen, T.; Kuosmanen, N. 2009. How not to measure sustainable value (and how one might), Ecological Economics 69(2): 235-243. http://dx.doi.org/10.1016/j.ecolecon.2009.08.008

Kurucz, E. C.; Colbert, B. A.; Wheeler, D. 2008. The business case for corporate social responsibility, Chapter 4 in A. Crane, A. McWilliams, D. Matten, J. Moon, D. S. Siegel (Eds.). The Oxford handbook of corporate social responsibility. Oxford: Oxford University Press. http://dx.doi.org/10.1093/oxfordhb/9780199211593.003.0004

Labuschagne, C.; Brent, A. C.; van Erck, R. P. G. 2005. Assessing the sustainability performances of industries, Journal of Cleaner Production 13(4): 373-385.

http://dx.doi.org/10.1016/j.jclepro.2003.10.007

Lamberton, G. 2005. Sustainable sufficiency - an internally consistent version of sustainability, Sustainable Development 13(1): 53-68. http://dx.doi.org/10.1002/sd.245

Lee, S.; Geum, Y.; Lee, H.; Park, Y. 2012. Dynamic and multidimensional measurement of productservice system (PSS) sustainability: a triple bottom line (TBL)-based system dynamics approach, Journal of Cleaner Production 32: 173-182. http://dx.doi.org/10.1016/j.jclepro.2012.03.032

Lee, S.; Singal, M.; Kang, K. H. 2013. The corporate social responsibility-financial performance link in the U.S. restaurant industry: do economic conditions matter?, International Journal of Hospitality Management 32: 2-10. http://dx.doi.org/10.1016/j.ijhm.2012.03.007

Lenox, M.; King, A. 2004. Prospects for developing absorptive capacity through internal information provision, Strategic Management Journal 25(4): 331-345. http://dx.doi.org/10.1002/smj.379 
Linnenluecke, M. K.; Griffiths, A. 2010. Corporate sustainability and organizational culture, Journal of World Business 45(4): 357-366. http://dx.doi.org/10.1016/j.jwb.2009.08.006

Loorbach, D. A.; Lijnis Huffenreuter, R. 2013. Exploring the economic crisis from a transition management perspective, Environmental Innovation and Societal Transitions 6: 35-46. http://dx.doi.org/10.1016/j.eist.2013.01.003

Loorbach, D.; Rotmans, J. 2010. The practice of transition management: examples and lessons from four distinct cases, Futures 42(3): 237-246. http://dx.doi.org/10.1016/j.futures.2009.11.009

López, M. V.; Garcia, A.; Rodriguez, L. 2007. Sustainable development and corporate performance: a study based on the Dow Jones sustainability index, Journal of Business Ethics 75(3): 285-300. http://dx.doi.org/10.1007/s10551-006-9253-8

Lozano, R.; Carpenter, A.; Huisingh, D. 2014. A review of "theories of the firm" and their contributions to Corporate Sustainability, Journal of Cleaner Production, 1-13.

http://dx.doi.org/10.1016/j.jclepro.2014.05.007

Mackenzie, C. 2007. Boards, incentives and corporate social responsibility: the case for a change of emphasis, Corporate Governance: an International Review 15(5): 935-943. http://dx.doi.org/10.1111/j.1467-8683.2007.00623.x

Mahoney, L. S.; Thorne, L.; Cecil, L.; LaGore, W. 2013. A research note on standalone corporate social responsibility reports: signaling or greenwashing?, Critical Perspectives on Accounting 24(4-5): 350-359. http://dx.doi.org/10.1016/j.cpa.2012.09.008

McWilliams, A.; Siegel, D. S.; Wright, P. M. 2006. Corporate social responsibility: strategic implications, Journal of Management Studies 43(1): 1-18. http://dx.doi.org/10.1111/j.1467-6486.2006.00580.x

Moneva, J. M.; Archel, P.; Correa, C. 2006. GRI and the camouflaging of corporate unsustainability, Accounting Forum 30(2): 121-137. http://dx.doi.org/10.1016/j.accfor.2006.02.001

Moore, S. B.; Manring, S. L. 2009. Strategy development in small and medium sized enterprises for sustainability and increased value creation, Journal of Cleaner Production 17(2): 276-282. http://dx.doi.org/10.1016/j.jclepro.2008.06.004

Mu, J.; Zhang, G.; MacLachlan, D. L. 2011. Social competency and new product development performance, IEEE Transactions on Engineering Management 58(2): 363-376. http://dx.doi.org/10.1109/TEM.2010.2099231

Neumayer, E. 2010. Weak versus strong sustainability: exploring the limits of two opposing paradigms. UK Northampton, MA, USA. http://dx.doi.org/10.4337/9781849805438

O'Connor, M.; Spangenberg, J. H. 2008. A methodology for CSR reporting: assuring a representative diversity of indicators across stakeholders, scales, sites and performance issues, Journal of Cleaner Production 16(13): 1399-1415. http://dx.doi.org/10.1016/j.jclepro.2007.08.005

Parmar, B. L.; Freeman, R. E.; Harrison, J. S.; Wicks, A. C.; Purnell, L.; Colle, S. D. 2010. Stakeholder theory: the state of the art, The Academy of Management Annals 4(1): 403-45. http://dx.doi.org/10.1080/19416520.2010.495581

Porter, M. E.; Kramer, M. R. 2006. Strategy and society: The link between competitive advantage and corporate social responsibility, Harvard Business Review 84(12): 78-92.

Porter, M. E.; Kramer, M. R. 2011. Creating Shared Value - how to reinvent capitalism and unleash a wave of innovation and growth, Harvard Business Review: 1-17.

Ramanathan, R.; Black, A.; Nath, P.; Muyldermans, L. 2010. Impact of environmental regulations on innovation and performance in the UK industrial sector, Management Decision 48(10): 1493-1513. http://dx.doi.org/10.1108/00251741011090298

Rivera-Camino, J. 2007. Re-evaluating green marketing strategy: a stakeholder perspective, European Journal of Marketing 41(11/12): 1328-1358. http://dx.doi.org/10.1108/03090560710821206 
Roca, L. C.; Searcy, C. 2012. An analysis of indicators disclosed in corporate sustainability reports, Journal of Cleaner Production 20(1): 103-118. http://dx.doi.org/10.1016/j.jclepro.2011.08.002

Rodrigo, L. 2012. Towards better embedding sustainability into companies' systems: an analysis of voluntary corporate initiatives, Journal of Cleaner Production 25: 14-26.

http://dx.doi.org/10.1016/j.jclepro.2011.11.060

Ruckelshaus, W. 1989. Toward a sustainable world, Scientific American 261(3): 166-175. http://dx.doi.org/10.1038/scientificamerican0989-166

Sakalauskas, L. 2010. Editorial: sustainability models and indicators, Technological and Economic Development of Economy 16(4): 567-577. http://dx.doi.org/10.3846/tede.2010.35

Santos, F. M.; Eisenhardt, K. M. 2005. Organizational boundaries and theories of organization, Organization Science 16(5): 491-508. http://dx.doi.org/10.1287/orsc.1050.0152

Searcy, C.; Elkhawas, D. 2012. Corporate sustainability ratings: an investigation into how corporations use the Dow Jones Sustainability Index, Journal of Cleaner Production 35: 79-92. http://dx.doi.org/10.1016/j.jclepro.2012.05.022

Sheate, W. R. 2012. Purposes, paradigms and pressure groups: accountability and sustainability in EU environmental assessment, 1985-2010, Environmental Impact Assessment Review 33(1): 91-102. http://dx.doi.org/10.1016/j.eiar.2011.11.001

Singh, R. K.; Murty, H. R.; Gupta, S. K.; Dikshit, A. K. 2007. Development of composite sustainability performance index for steel industry, Ecological Indicators 7(3): 565-588. http://dx.doi.org/10.1016/j.ecolind.2011.01.007

Singh, R. K.; Murty, H. R.; Gupta, S. K.; Dikshit, A. K. 2009. An overview of sustainability assessment methodologies, Ecological Indicators 9(2): 189-212. http://dx.doi.org/10.1016/j.ecolind.2008.05.011

Smith, N. C. 2003. Corporate social responsibility: whether or how?, California Management Review 45(4): 52-76. http://dx.doi.org/10.2307/41166188

Stuart, L. H.; Mark, B. M.; Joseph, C. 2003. Creating sustainable value, The Academy of Management Executive 17(2): 56-69. http://dx.doi.org/10.5465/AME.2003.10025194

UN. 2008. International standard industrial classification of all economic activities. Department of Economic and Social Affairs Statistics Division United Nations Series M No. 4/Rev.4: 291.

UNEP. 2012. The emissions gap report 2012, United Nations Environment Programme (UNEP) [online], [cited 10 April 2014]. Nairobi. Available from Internet: http://wwwuneporg/publications/ebooks/ emissionsgap2012/

Urban, B.; Nikolov, K. 2013. Sustainable corporate entrepreneurship initiatives: a risk and reward analysis, Technological and Economic Development of Economy 19(Sup 1): S383-S408.

Van Passel, S.; Nevens, F.; Mathijs, E.; Van Huylenbroeck, G. 2007. Measuring farm sustainability and explaining differences in sustainable efficiency, Ecological Economics 62(1): 149-161. http://dx.doi.org/10.1016/j.ecolecon.2006.06.008

Vitaliano, D. F. 2010. Corporate social responsibility and labor turnover, Corporate Governance 10(5): 563-573. http://dx.doi.org/10.1108/14720701011085544

Waddock, S. A.; Graves, S. B. 1997. The Corporate Social Performance - financial performance link, Strategic Management Journal 18(4): 303-319. http://dx.doi.org/10.1002/(SICI)1097-0266(199704)18:4<303::AID-SMJ869>3.0.CO;2-G

Walker, B. H.; Salt, D. 2006. Resilience thinking: sustaining ecosystems and people in a changing world. USA, DC, Washington: Island Press, 192.

WBCSD. 2010. Vision 2050 - the new agenda for business. Geneve, 80.

Wood, D. J. 2010. Measuring corporate social performance: a review, International Journal of Management Reviews 12(1): 50-84. http://dx.doi.org/10.1111/j.1468-2370.2009.00274.x 
Winston JERÓNIMO SILVESTRE has a PhD degree in Sustainable Development and Environment from the Faculty of Science and Technology - New University of Lisbon. A researcher in ISEG/SOCIUS Lisbon School of economics \& Management - University of Lisbon. Her research interests are in the evaluate strategies and assessment of corporate sustainability. Has a background in additional skills in quality management, industrial engineering and has strong experience in management and economics.

Paula ANTUNES. She is Full Professor at the Department of Environmental Sciences and Engineering, teaching environmental management, both in graduate and undergraduate courses. She received her PhD degree in Environmental Systems from the New University of Lisbon, and works in ecological economics, namely in the fields of sustainability studies, environmental management and environmental assessment and modelling. Paula Antunes has a background in environmental engineering and has a strong experience in developing interdisciplinary work and coordinating multidisciplinary research teams.

Walter LEAL FILHO. He holds the Chair of Environment and Technology, at the School of Science and the Environment at Manchester Metropolitan University, UK. He is in charge of various international projects on environment and sustainable development issues. 